JURNAL RISET KESEHATAN NASIONAL

VOL. 5 NO. 1 Halaman 13-16

$P-I S S N$ : 2580-6173

$E-I S S N: 2548-6144$

Available Online http://ojs.itekes-bali.ac.id/index.php/jrkn/index

\title{
SELF CARE PADA PASIEN DIABETES MELITUS DENGAN PENYULIT ULKUS KAKI DIABETIK
}

\author{
(Diabetes Self Care in Diabetic Foot Ulcers)
}

\author{
Sri Dewi Megayanti*, Inge Ruth Suantika** \\ $\left.{ }^{*}\right),{ }^{* *}$ Institut Teknologi dan Kesehatan Bali,Jalan Tukad Balian No.180 Renon \\ Denpasar-Bali \\ Email : megayanti.pande28@gmail.com
}

\begin{abstract}
ABSTRAK
Latar Belakang: Diabetes self-care merupakan perilaku perawatan diri pasien diabetes yang meliputi pengaturan diet, penggunaan insulin, olahraga dan perawatan kaki. Diabetes self-care memiliki efek langsung pada kontrol glikemik dalam terjadinya ulkus kaki diabetic. Skor PEDIS merupakan form pemeriksaan yang digunakan perawat dalam menilai keparahan ulkus kaki. Keterbatasan intervensi ulkus kaki yang diberikan oleh perawat saat ini disebabkan oleh terbatasnya data tentang self-care pada pasien diabetes. Tujuan penelitian mengetahui self-care pasien diabetes dengan komplikasi ulkus kaki menggunakan metode pengukuran skor PEDIS yang teridiri dari pemeriksaan perfusi, luas luka, kedalaman luka, keberadaan infeksi dan sensasi kaki.

Metode: Penelitian ini termasuk penelitian kuantitatif, dimana penentuan responden menggunakan teknik Convenience sampling dengan jumlah sampel adalah 125 , analisa data yang digunakan dengan metode deskriptif.

Hasil: Pada penelitian ini 53,8 \% reponden memiliki diabetes self-care yang adekuat dan rata- rata responden memiliki Skor PEDIS 2,08.

Kesimpulan: dalam penelitian ini sebagian besar responden memiliki diabetes self-care yang tidak adekuat. Nilai Diabetes self-care dapat digunakan oleh perawat untuk mengetahui tingkat kualitas perawatan diri pasien selama ini sehingga memudahkan dalam menentukan intervensi yang tepat untuk mencegah terajadinya perburukan ulkus kaki.
\end{abstract}

Kata kunci: diabetes mellitus tipe 2, diabetes self-care, dan ulkus kaki diabetik.

\begin{abstract}
Background: Diabetes self-care is a diabetes patient self-care behavior that includes diet management, insulin use, exercise and foot care. Diabetes self-care has a direct effect on glycemic control in the occurrence of diabetic foot ulcers. The PEDIS score is an examination form that nurses use in assessing the severity of foot ulcers. The limitations of the foot ulcer intervention given by nurses at this time are due to limited data on self-care in diabetic patients. The aim of this study was to determine the self-care of diabetic patients with complications of foot ulcers using the PEDIS score measurement method which consists of examination of perfusion, wound area, wound depth, presence of infection and foot sensation.

Methods: This research is a quantitative study, where the determination of the respondents using the convenience sampling technique with a sample size of 125, the data analysis used is the descriptive method.

Results: In this study 53.8\% of respondents had adequate diabetes self-care and the mean of respondents had a PEDIS score of 2.08 .
\end{abstract}


Conclusion: in this study most of the respondents had inadequate self-care diabetes. The value of diabetes self-care can be used by nurses to determine the level of quality of patient self-care so far, making it easier to determine the right intervention to prevent worsening of foot ulcers.

Keywords: type 2 diabetes mellitus, diabetes self-care, and diabetic foot ulcers.

\section{LATAR BELAKANG}

Diabetes mellitus (DM) adalah penyakit endokrin dan metabolik yang melibatkan kegagalan penggunaan atau produksi insulin. Kumpulan penyakit pada DM terjadi akibat tingginya kadar glukosa darah melebihi batas normal (Bilous, R \& Donelly, 2015). Pada tahun 2015 angka kejadian penyakit DM di dunia sekitar 415 juta orang dan terus mengalami peningkatan sebesar 54 yaitu menjadi 642 juta orang di tahun 2040. (IDF, 2015). Di Indonesia jumlah penduduk yang mengidap penyakit diabetes sebesar 10 juta orang pada tahun 2015 dan diprediksi akan meningkat sampai 16, 2 juta orang pada tahun 2040.

Kondisi hiperglikemik yang tidak terkontrol menyebabkan komplikasi akut DM seperti ketoasidosis diabetik, hiperosmolar non ketotik, dan hipoglikemia serta komplikasi kronis yang berupa angiopati pada mikrovaskuler dan makrovaskuler (Sacco et al., 2011). Ulkus kaki diabetik merupakan salah satu komplikasi kronik yang sering terjadi akibat buruknya kontrol glikemik. Kondisi hiperglikemia kronis menyebabkan terjadinya neuropati perifer, penyakit pembuluh darah arteri perifer dan gangguan resistensi terhadap infeksi yang memperparah kondisi ulkus kaki diabetik (Noor et al., 2015).

Diabetes Self-care merupakan perilaku perawatan diri pasien diabetes yang meliputi pengaturan diet, penggunaan insulin, olahraga dan perawatan kaki ( $T$ Ype 2 Diabetes in Adults: Management NICE 2017, 2017). Penelitian yang dilakukan oleh Gao,et al di Cina pada 222 pasien untuk menilai hubungan perilaku self-care dengan kontrol glikemik pasien, dari penelitian tersebut diperoleh hasil menunjukkan bahwa hampir semua perilaku perawatan diri yang tepat secara positif berkaitan dengan kontrol glikemik yang baik antara pasien dengan diabetes. Diabetes self-care memiliki efek langsung pada kontrol glikemik $(\beta=-0,21, \mathrm{p}=$ 0,007) (Gao et al., 2013).

Berdasarkan studi lapangan yang dilakukan oleh peneliti pada tahun 2018-2019 terhadap 130 pasien DM yang melakukan kunjungan pelayanan kesehatan, bahwa selama ini perawat mengalami kesulitan didalam memberikan intervensi pada pasien diabetes sehingga pasien mengalami kondisi glikemik yang tak terkontrol yang pada akhirnya terjadi ulkus kaki. Keterbatasan intervensi yang diberikan disebabkan oleh terbatasnya data tentang data self-care pada pasien diabetes.

Diperlukannya studi penelitian untuk menggali diabetes self-care lebih dalam lagi pada pasien diabetes perlu dilakukan untuk membantu perawat dalam menentukan edukasi perawatan. Sehingga pasien dapat menerima informasi lebih tepat tentang pengelolaan DM untuk mencegah ulkus kaki. Berdasarkan data diatas peneliti ingin mengkaji lebih dalam tentang bagaimana gambaran self-care pada pasien diabetes melitus yang mengalami ulkus kaki. Perawat sebagai salah satu tenaga kesehatan yang secara langsung memberikan layanan kesehatan pada pasien dipandang perlu untuk mengetahui sejauh mana perawatan diri pasien dirumah. Hal tersebut bertujuan untuk mempermudah perawat dalam pemberian edukasi saat pasien diabetes melakukan kunjungan pengobatan ke RS maupun ke klinik pelayanan kesehatan dan membantu pasien dalam melakukan perawatan diri yang tepat untuk mencegah ulkus kaki.

Dengan didapatkannya informasi mengenai self-care pada pasien diabetes dengan ulkus kaki diabetik diharapkan dapat membantu pasien mencegah terjadinya penyulit ulkus kaki sehingga dapat meneingkatkan kualitas hidup pasien diabetes. Tujuan penelitian ini adalah untuk mengetahui selfcare pasien diabetes dengan komplikasi ulkus kaki menggunakan skor PEDIS.

\section{METODE}

Jenis penelitian ini termasuk penelitian kuantitatif dengan metode deskriptif. Populasi dalam penelitian ini ialah seluruh pasien DM tipe 2 yang melakukan kunjungan dan perawatan pada yaitu di Pusat Pelayanan Kesehatan Masyarakat Denpasar Bali . Variabel dalam penelitian ini adalah Self-care pada pasien DMT 2 dengan komplikasi ulkus kaki

Jurnal Riset Kesehatan Nasional hal. 14 
menggunakan metode pengukuran skor PEDIS.

Penelitian ini menggunakan teknik Convenience sampling dengan penentuan besar sampel menggunakan rumus Slovin. Jumlah sampel yang memenuhi kriteria sampel adalah 126 dengan kriteria inklusi, berusia 45- 65 tahun, dapat berkomunikasi verbal dengan baik, mampu membaca dan menulis dan diabetes melitus dengan komplikasi ulkus kaki diabetik atau beresiko ulkus kaki. Sedangkan kriteria eksklusinya yaitu, Klien DM type 2 yang mempunyai keterbatasan fisik, mental dan kognitif seperti buta,tuli dan cacat mental dan klien DM type 2 yang mengalami komplikasi seperti nefropati, cardiomiopati.

Pengumpulan data self-care menggunakan kuesioner the summary diabetes self-care activity (SDSCA) dan penilaian ulkus kaki menggukan PEDIS skoring yang terdiri dari terdiri dari 5 jenis pemeriksaan yaitu pemeriksaan perfusi kaki, luas luka, kedalaman luka, kondisi infeksi dan sensasi proteksi kaki. Score PEDIS akan diberikan rentang skor 0 sampai 3 . Dimana total nilai PEDIS 0 sampai 12 , dengan nilai minimun 0 dan maksimum 12. Kedua jenis instrumen yang digunakan sudah dilakukan uji validitas dan reliabilitas.

Analisa data yang digunakan dalam penelitian ini adalah statistik deskriptif untuk mengetahui sebaran proporsi data self-care dan nilai median dari skor PEDIS pada pasien Diabetes. Etika penelitian ini berdasarkan standar etika penelitian yang didasarkan dengan beneficence/kebaikan, respect for human dignity /menghormati martabat manusia, dan justice/keadilan . Uji etik dilakukan sebelum penelitian oleh Komisi Etik Penelitian Itekes Bali.

\section{HASIL}

Tabel 1.

Distribusi responden berdasarkan diabetes self-care

\begin{tabular}{lll}
\hline Variabel & Jumlah & $\begin{array}{c}\text { Persen- } \\
\text { tase (\%) }\end{array}$ \\
\hline Diabetes Self-care & & \\
$\quad$ Adekuat & 67 & 53,8 \\
$\quad \begin{array}{l}\text { Tidak ad- } \\
\text { ekuat }\end{array}$ & 59 & 46,2 \\
\begin{tabular}{l} 
Total \\
\hline
\end{tabular} & 126 & 100 \\
\hline
\end{tabular}

Berdasarkan tabel distribusi diabetes Selfcare responden dapat dijelaskan bahwa sebagian besar responden memiliki tingkat diabetes self-care adekuat yaitu 57 responden $(53,8$ $\%)$.

Tabel 2

Distribusi responden berdasarkan score PEDIS

\begin{tabular}{lllll}
\hline $\begin{array}{l}\text { Varia- } \\
\text { bel }\end{array}$ & $\begin{array}{l}\text { Rata- } \\
\text { rata }\end{array}$ & Varian & $\begin{array}{l}\text { Min- } \\
\text { max }\end{array}$ & 95\%Cl \\
Score & 2,08 & 5,164 & $0-9$ & $\begin{array}{l}1,652- \\
2,52\end{array}$ \\
PEDIS & & & & 2,55 \\
\hline
\end{tabular}

Distribusi responden berdasarkan score PEDIS menunjukkan nilai mean $2,08 \quad(95 \% \mathrm{CI} \quad 1,652-$ 2,52 ), nilai score PEDIS minimum 0 dan nilai score PEDIS maksimum 9 dengan varian 5,164.

\section{PEMBAHASAN}

Pada penelitian ini mayoritas reponden yaitu sebesar $67(53,8 \%)$ responden memiliki diabetes self-care yang adekuat denga. Sedangkan responden yang memiliki tingkat diabetes self-care yang tidak adekuat sebesar $59(46,2)$ responden. Pasien diabetes yang memiliki score self-care tinggi artinya memiliki perawatan diri yang baik dimana mereka dapat mengontrol makanan, rutin untuk berolahraga, tepat dalam mengonsumsi obat diabetes, rutin memeriksa gula darahnya dan selalu memperhatikan kondisi kaki melalui perawatan kaki cenderung memiliki resiko rendah terjadi komplikasi ulkus pada kaki (Albikawi \& Abuadas, 2015).

Berdasarkan sebaran data skor PEDIS didapatkan rata-rata responden pada penelitian ini memiliki skor PEDIS 2,08. Pada penanganan diabetes, pasien diharapkan mengikuti serangkaian tindakan perilaku yang kompleks untuk merawat diabetes mereka setiap hari. Tindakan ini melibatkan perilaku hidup seperti mengikuti rencana makan dan melakukan aktivitas fisik yang tepat, minum obat (insulin atau agen hipoglikemik oral), memantau kadar glukosa darah, mengikuti panduan perawatan kaki dan rutin melakukan kontrol penyakit diabetes (R \& Abdul, 2016).

Menurunkan kadar glukosa darah pasien merupakan tujuan dari pengelolaan diri diabetes tetapi tidak dapat menjadi satu-satunya tujuan dalam perawatan pasien diabetes (Ahmad et al., 2014). Hal lain yang juga perlu diperhatikan dalam pengelolaan DM seperti mencegah terjadinya komplikasi dan

Jurnal Riset Kesehatan Nasional hal. 15 
pengobatan yang tepat terhadap komplikasi yang sudah terjadi akibat penyakit yang kronis. Perubahan dalam aktivitas perawatan diri juga harus dievaluasi secara berkala untuk mengetahui kemajuan dari perubahan perilaku yang terjadi pada pasien DM (Chamberlain et al., 2016).

Kondisi ulserasi dan amputasi yang terjadi pada pasien dengan diabetes menunjukkan komplikasi terjadi karena kurangnya efektivitas perawatan diri (Lu et al., 2016) Kegiatan perawatan diri mengacu pada perilaku seperti mengikuti rencana diet, menghindari makanan berlemak tinggi, latihan, pemantauan glukosa, pengobatan dan perawatan kaki. Apabila pasien DM mampu menerapkan perilaku tersebut secara berkepanjangan, maka komplikasi salah satunya ulkus kaki diabetik dapat dicegah (Pérez et al., 2017)

\section{KESIMPULAN DAN SARAN Kesimpulan}

Berdasarkan penelitian yang sudah dilakukan dapat disimpulkan sebagian besar responden memiliki diabetes self-care yang adekuat dengan rata-rata responden memiliki skor ulkus kaki 2,08.

\section{Saran}

Perawat dapat menggunakan hasil dari evaluasi diabetes self-care sebagai indikator tingkat keparahan dari ulkus kaki pada pasien diabetes. Sehingga perawat dapat dengan mudah untuk mengambil keputusan yang tepat terhadap intervensi dan kolaborasi yang akan dilakukan selanjutnya. Hal tersebut ditujukan untuk pencapaian hasil yang lebih efektif terhadap kontrol glikemik pasien serta dapat mencegah perburukan komplikasi akibat diabetes.

KEPUSTAKAAN

Oxidative Stress and Dietary Antioxidants,
2013, 3-13. https://doi.org/10.1016/ B978-0-12-405885-9.00001-2

Pérez, A., Santamaria, E. K., Operario, D., Tarkang, E. E., Zotor, F. B., Cardoso, S. R. de S. N., Autor, S. E. U., De, I., Dos, A., Vendas, O. D. E., Empresas, D. A. S., Atividades, P. O., Artigo, N., Gest, G. N. R. M. D. E., Para, D. E. F., Miranda, S. F. da R., Ferreira, F. A. A., Oliver, J., Dario, M., ... Volk, J. E. (2017). No 主観的健康感を中心とした在宅高齢 者における＼cjkstart健康関連指標に関する 共分散構造分析Title. BMC Public Health, 5(1), 1-8. https:// ejournal.poltektegal.ac.id/index.php/ siklus/article/view/298\%0Ahttp:// repositorio.unan.edu.ni/2986/1/5624.pdf\% 0Ahttp://dx.doi.org/10.1016/ j.jana.2015.10.005\%0Ahttp:// www.biomedcentral.com/14712458/12/58\%0Ahttp://ovidsp.ovid.com/ ovidweb.cgi?T $=\mathrm{JS} \& \mathrm{P}$

R, J., \& Abdul, J. A. (2016). a Study To Find the Correlation Between Self-Care and Glycemic Control of Diabetic Clients in a Selected Tertiary Care Hospital. International Journal of Research in Ayurveda \& Pharmacy, 7(2), 71-74. https:// doi.org/10.7897/2277-4343.07260

Sacco, M. W. P., Ph, D., Jacobsen, P. B., Ph, D., Small, B. J., \& Ph, D. (2011). The Role of Microvascular Complications in the Relationship between Glycemic Control and Depressive Symptomatology in Patients with Type 1 Diabetes: A Mediational Study by Laura L . Mayhew A thesis submitted in partial fulfillment of the requirements for.

$T$ ype 2 diabetes in adults: management NICE 2017. (2017). December 2015, 117. 